\title{
Synthesis, Characterisation, and Biological Evaluation of Zn(II) Complex with Tridentate (NNO Donor) Schiff Base Ligand
}

\author{
Nayaz Ahmed, ${ }^{1}$ Mohd Riaz, ${ }^{2}$ Altaf Ahmed, ${ }^{3}$ and Madhulika Bhagat ${ }^{4}$ \\ ${ }^{1}$ Department of Chemistry, Sadhu Vaswani College, Bairagarh, Bhopal 462030, India \\ ${ }^{2}$ Department of Chemistry, Govt. P.G. College Rajouri, Rajouri, Jammu and Kashmir 185131, India \\ ${ }^{3}$ P.G. Department of Chemistry, University of Jammu, Jammu and Kashmir 180006, India \\ ${ }^{4}$ School of Biotechnology, University of Jammu, Jammu and Kashmir 180006, India
}

Correspondence should be addressed to Nayaz Ahmed; nayazchoudhary1986@gmail.com

Received 19 September 2014; Revised 12 November 2014; Accepted 20 November 2014

Academic Editor: Alfonso Castiñeiras

Copyright (C) 2015 Nayaz Ahmed et al. This is an open access article distributed under the Creative Commons Attribution License, which permits unrestricted use, distribution, and reproduction in any medium, provided the original work is properly cited.

\begin{abstract}
The present paper deals with the synthesis and characterization of metal complex of tridentate Schiff base ligand derived from the inserted condensation of 2-aminobenzimidazole (1H-benzimidazol-2-amine) with salicylaldehyde (2-hydroxybenzaldehyde) in a 1:1 molar ratio. Using this tridentate ligand, complex of $\mathrm{Zn}(\mathrm{II})$ with general formula ML has been synthesized. The synthesized complex was characterized by several techniques using molar conductance, elemental analysis, FT-IR, and mass and ${ }^{1} \mathrm{HNMR}$ spectroscopy. The elemental analysis data suggest the stoichiometry to be $1: 1[\mathrm{M}: \mathrm{L}]$. The complex is nonelectrolytic in nature as suggested by molar conductance measurements. Infrared spectral data indicate the coordination between the ligand and the central metal ion through deprotonated phenolic oxygen, imidazole nitrogen of benzimidazole ring, and azomethine nitrogen atom. Spectral studies suggest tetrahedral geometry for the complex. The pure compound, synthesized ligand, and metal complex were screened for their antimicrobial activity.
\end{abstract}

\section{Introduction}

Metal complexes of Schiff base have played a central role in the development of coordination chemistry [1]. Various Schiff base complexes have been widely studied because they have antimicrobial, anticancer, analgesic, anti-inflammatory, antifertility, and herbicidal applications $[2,3]$. Chelating ligands containing $\mathrm{N}, \mathrm{N}$, and $\mathrm{O}$ donor atoms show broad biological activity and are of special interest because of the ways in which they are bonded to the metal ions [4]. It is known that existence of metal ions bonded to biologically active compounds may enhance their activities [5-7]. Even though many Schiff bases using salicylaldehyde and substituted salicylaldehydes and amines had been studied [811] as ligands, no work had been done with salicylaldehyde and 2-aminobenzimidazole as the basic nucleus of Schiff bases. Schiff base metal complexes had been a widely studied subject to their industrial and biological applications [12]. The synthesis, physicochemical characterization, and biological activity of 2-aminobenzimidazole complexes with different metal ions have been reported [13]. An efficient synthesis of Schiff bases containing benzimidazole moiety catalysed by transition metal nitrates had been done [14]. The synthesis and antimicrobial activity of $\mathrm{Cu}(\mathrm{II}), \mathrm{Co}(\mathrm{II})$, and $\mathrm{Ni}(\mathrm{II})$ complexes with 2-aminobenzimidazole were available [15].

\section{Experimental}

2.1. Chemicals. All the chemicals used were of AR/GR grade. Pure sample of 2-aminobenzimidazole (Ab), molecular formula $\mathrm{C}_{7} \mathrm{H}_{7} \mathrm{~N}_{3}$, molecular weight $133.15 \mathrm{~g} / \mathrm{mol}$, melting point $229-231^{\circ} \mathrm{C}$ was obtained from Himedia Pharmaceuticals Ltd. (Figure 1). Metal salt of $\mathrm{ZnCl}_{2}$ was of Merck chemicals. Solvents used were ethanol, acetone, and DMF.

2.2. Synthesis of Schiff Base. The Schiff base was prepared by mixing equimolar amounts of 2 -aminobenzimidazole and the aromatic aldehyde in ethanol. The mixture was refluxed for about 4 hours. Concentration of the solution was done to 
<smiles>Nc1nc2ccccc2[nH]1</smiles>

FIGURE 1: Structure of pure compound (2-aminobenzimidazole).<smiles>Oc1ccccc1/C=N/c1nc2ccccc2[nH]1</smiles>

FIGURE 2: Structure of Schiff base.

reduce it to one-half of its original volume and kept for 4-5 days when deep yellow crystals were formed in the reaction mixture, which were filtered, washed thoroughly with the same solvent, and recrystallized with acetone. The yellow Schiff base product obtained (m.p. $142^{\circ} \mathrm{C}$ ) produced in $54 \%$ yield was subjected to analysis (Figure 2).

2.2.1. Synthesis of the Complex. For the synthesis of complex, $\mathrm{Ab}-\mathrm{S}-\mathrm{Zn}$, ligand-metal ratio was determined by conductometric titration using monovariation method on Systronics conductivity meter using dip type electrode. $20 \mathrm{~mL}$ of the ligand $(0.01 \mathrm{M})$ was diluted to $200 \mathrm{~mL}$ using pure ethanol and titrated against $\mathrm{ZnCl}_{2}(0.02 \mathrm{M})$ solution prepared in the same solvent. Conductance was recorded after each addition of metal salt solution. Graph is plotted between corrected conductance and volume of metal salt added.

From the equivalence point in the graph, it has been concluded that the complex formation of the ligand with the metal takes place in the ratio $1: 1(\mathrm{~L}: \mathrm{M})$. Conductometric titration supported $1: 1(\mathrm{~L}: \mathrm{M})$ ratio in the complex, which was further supported by Job's method of continuous variation as modified by Turner and Anderson.

$0.02 \mathrm{M}$ solution of Ab-S and $0.02 \mathrm{M}$ metal salt solution were prepared separately in pure ethanol and mixed. Colour of the resulting solution was yellow green. The $\mathrm{pH}$ of the solution was raised to 7.5 by adding $\mathrm{N} / 10 \mathrm{NaOH}$ solution. This solution was refluxed for 4 hours and kept for four days when pale green coloured product was obtained. This product was then filtered, washed with the same solvent, dried over fused $\mathrm{CaCl}_{2}$, weighed, and subjected to analysis.

2.3. Physical Measurements. Elemental analysis was carried out on Vario MICRO V2.20 Elemental Analyser System $\mathrm{GmbH}$, from IIIM, Jammu. Metal contents were determined gravimetrically [16]. The infrared spectra were recorded on FT-InfraRed Spectrophotometer Model RZX (Perkin Elmer) using $\mathrm{KBr}$ pellets, from SAIF, Punjab University, Chandigarh. Molar conductance measurement was made in $10^{-3} \mathrm{M}$ DMF solution on a Systronics direct reading conductivity meter (Model 303).

The melting points of the ligand and the complex were recorded in open capillaries on a capillary melting point apparatus. The NMR spectra were recorded at SAIF/CIL, PU, Chandigarh, by NMR spectrophotometer. The mass spectra was recorded at SAIF/CIL, PU, Chandigarh, by LCMS spectrometer model Q-ToF Micro Waters.

2.4. In Vitro Antimicrobial Activity. Qualitative analysis for screening of antibacterial activity of Schiff base and its complex was carried out by agar well diffusion method (Table 3) $[17,18]$ with modifications. The compounds were tested against two gram positive and two gram negative bacteria at concentration $10^{-3}$ M. $20 \mathrm{~mL}$ of sterilized nutrient agar was inoculated with $100 \mathrm{~mL}$ of bacterial suspension $\left(10^{8} \mathrm{CFU} / \mathrm{mL}\right)$ and then poured on to sterilized petri plate. The agar plate was left to solidify at room temperature.

A well of $6 \mathrm{~mm}$ was asceptically bored into the agar plate. Then, $20 \mathrm{~mL}$ of the complexes (diluted with DMSO, 1:1) was added in each well. Chloramphenicol $(10 \mu \mathrm{g})$ was used as a positive reference to determine the sensitivity of bacteria. The plates were kept at $4^{\circ} \mathrm{C}$ for 2 hours to allow the dispersal and then incubated.

Definite volumes of peptone ( $5 \mathrm{gm})$, beef extract ( $3 \mathrm{gm})$, and agar $(15 \mathrm{gm})$ were dissolved in distilled water to prepare the nutrient agar and $\mathrm{pH}$ was adjusted to 7.2. This solution was sterilized by autoclaving at 15 psi for 20 minutes.

The in vitro antifungal activity by agar well diffusion method [19] was standardized using Griseofulvin. Sabouraud's dextrose agar medium was used as the nutrient medium (HiMedia fungi used). The medium was prepared by dissolving in water and autoclaving at $121^{\circ} \mathrm{C}$ for 15 minutes. Standard cultures of Candida albicans and Aspergillus niger were employed for the present study.

Griseofulvin standard was prepared at a final concentration of $10 \mu \mathrm{g} / \mathrm{mL}$ in sterile distilled water. The surface of Sabouraud's agar plate was dried at $35^{\circ} \mathrm{C}$. Later bores in plate were made using sterile cork borer. A control having only DMSO was maintained in each plate. The plates were incubated at $35^{\circ} \mathrm{C}$ for $48 \mathrm{hrs}$. Later the values of zones of inhibition were recorded. The plates were left for diffusion for one hour in the refrigerator and then incubated at $25^{\circ} \mathrm{C}$ and the inhibition zone for $C$. albicans was recorded after 24 hours of incubation. The zone of $A$. niger was recorded after 36 hours of incubation.

\section{Results and Discussion}

The reaction in solution between the ligand and transition metal cation may proceed by the following general equation:

$$
\mathrm{MX}_{n}+n \mathrm{HL} \longrightarrow \mathrm{ML}_{n}+n \mathrm{HX}
$$

where $n=1$ or $3 ; \mathrm{M}=\mathrm{Zn}(\mathrm{II})$; and $\mathrm{X}=$ corresponding anion of metal salt.

The metal complex is formed in $1: 1$ stoichiometric ratio. The ligand and the metal (II) complex were isolated pure from EtOH in good yields and they are of various colours. The ligand is yellow whereas the complex is pale green in colour. The complex gets decomposed up to $245^{\circ} \mathrm{C}$. They are very air stable solids at room temperature without decomposition for a long time. The complex is nonhygroscopic and insoluble 
TABLE 1: Analytical and physicochemical data of Schiff base and its metal complex.

\begin{tabular}{|c|c|c|c|c|c|c|c|c|c|}
\hline \multirow{2}{*}{ Ligand/complex } & \multirow{2}{*}{\multicolumn{2}{|c|}{$\mathrm{M}: \mathrm{L}$ Mol. Wt. }} & \multicolumn{4}{|c|}{ Elemental analysis found (calcd.) (\%) } & \multirow{2}{*}{ Colour (yield\%) } & \multirow{2}{*}{ M.Pt. $\left({ }^{\circ} \mathrm{C}\right)$} & \multirow{2}{*}{$\begin{array}{l}\mathrm{Scm}^{2} \\
\mathrm{~mol}^{-1}\end{array}$} \\
\hline & & & $\mathrm{C}$ & $\mathrm{H}$ & $\mathrm{N}$ & M & & & \\
\hline $\begin{array}{l}\mathrm{HL}] \\
\mathrm{C}_{14} \mathrm{H}_{11} \mathrm{~N}_{3} \mathrm{O}\end{array}$ & - & 237.25 & $70.87(70.80)$ & $4.67(4.58)$ & $17.71(17.59)$ & - & Yellow $(65 \%)$ & 142 & - \\
\hline $\begin{array}{l}\mathrm{C}_{14} \mathrm{H}_{10} \mathrm{~N}_{3} \mathrm{OCl} \\
\mathrm{Zn}\end{array}$ & $1: 1$ & $(337.09)$ & $50.80(49.76)$ & $2.37(2.46)$ & $14.41(13.47)$ & $19.65(19.50)$ & Pale green (63) & 245 (decomposition) & 18.0 \\
\hline
\end{tabular}

TABLE 2: Important IR spectral bands $\left(\mathrm{cm}^{-1}\right)$ of the ligand and its complex.

\begin{tabular}{lcccccccc}
\hline Ligand/complex & $\nu_{(\mathrm{C}=\mathrm{N})}$ & $\nu_{(\text {Cyclic } \mathrm{C}=\mathrm{N})}$ & $\nu_{(\text {Cyclic } \mathrm{C}-\mathrm{N})}$ & $\nu_{(\mathrm{CO})}$ & $\nu_{(\mathrm{M}-\mathrm{Cl})}$ & $\nu_{(\mathrm{M}-\mathrm{N})}$ & $\nu_{(\mathrm{M}-\mathrm{O})}$ & $\nu_{(\text {chelate ring })}$ \\
\hline $\mathrm{Ab}-\mathrm{S}$ & $1609 \mathrm{~s}$ & $1569 \mathrm{~s}$ & $1439 \mathrm{~s}$ & $1273 \mathrm{~s}$ & - & - & - & - \\
{$[\mathrm{Zn}(\mathrm{Ab}-\mathrm{S}) \mathrm{Cl}]$} & $1642 \mathrm{~b}$ & $1519 \mathrm{w}$ & $1465 \mathrm{~s}$ & $1272 \mathrm{~s}$ & $335 \mathrm{~s}$ & $508 \mathrm{~m}$ & $648 \mathrm{~s}$ & $1319 \mathrm{~s}$ \\
\hline
\end{tabular}

in water and other common organic solvents but soluble in DMF and DMSO. The molar conductance value of the complex (measured in $10^{-3} \mathrm{MDMSO}$ ) is $18.0 \mathrm{Scm}^{2} \mathrm{~mol}^{-1}$, indicating the nonelectrolytic nature [20] of the complex. The analytical data and molar conductance values are given in Table 1.

3.1. IR Spectral Study. The comparative analysis of the IR spectra of the complex and of the free ligand (Table 2) revealed that the absorption band characteristic of the stretching vibrations of $-\mathrm{C}=\mathrm{N}-$ (azomethine group) is shifted towards higher wave number from $1609 \mathrm{~cm}^{-1}$ in the spectrum of the ligand to $1642 \mathrm{~cm}^{-1}$ in the complex $[8,21]$. This indicates the coordination of the nitrogen of this group with the metal ion [22]. A broadband appearing at $\sim 3566 \mathrm{~cm}^{-1}$ assigned to $v_{\mathrm{O}-\mathrm{H}}$ in the Schiff base was no longer found in the spectra of the investigated metal complex [23] and, instead, appearance of a new band at $1272 \mathrm{~cm}^{-1}$ due to $\nu_{(\mathrm{C}-\mathrm{O})}$ stretching vibrations indicated deprotonation and coordination of the hydroxyl oxygen to the metal ion [24]. In addition, the appearance of new band at $335 \mathrm{~cm}^{-1}$ showing the involvement of $\mathrm{M}-\mathrm{Cl}$ bond in complex formation, supporting the IR spectral study. Further conclusive evidence of coordination of the Schiff base with the metal ion was shown by the appearance of low frequency new band at $648 \mathrm{~cm}^{-1}$ due to metal-oxygen $\nu_{(\mathrm{M}-\mathrm{O})}$ vibrations $[25,26]$ and was observed in the spectra of the thus confirming participation of the oxygen atom in the coordination. Further coordination of metal to azomethine nitrogen is confirmed by a new band at $508 \mathrm{~cm}^{-1}$ with the involvement of the imidazole ring nitrogen in the coordination with metal ion [27] due to $\nu_{(\mathrm{M}-\mathrm{N})}$.

3.2. ${ }^{1}$ H NMR Spectra. ${ }^{1} \mathrm{H}$ NMR spectrum of the ligand (AbS) shows a signal at $12.39 \mathrm{ppm}$ as singlet due to phenolic $-\mathrm{OH}[28]$. In the complex $\mathrm{Ab}-\mathrm{S}-\mathrm{Zn}$, the absence of any signal due to phenolic proton $(-\mathrm{OH})$ in this region indicates the involvement of phenolic oxygen in coordination via deprotonation [29], thus further supporting the IR spectral observations. In the ligand, the signal at $9.63 \mathrm{ppm}$ as singlet due to proton of azomethine group [30] shows an upfield shifting of $1.18 \mathrm{ppm}$ and appears at $10.81 \mathrm{ppm}$ in the complex indicating the coordination of azomethine nitrogen with metal ion [31]. The signals for the ligand were obtained at 8.16-6.84 ppm [32] due to protons of aromatic rings (8H, Ar$\mathrm{H})$ which gets shifted to higher field in the complexes due to shielding and appears as singlet and multiplet.

3.3. Mass Spectra. The mass spectrum of $\left[\mathrm{Zn}\left(\mathrm{C}_{14} \mathrm{H}_{10} \mathrm{~N}_{3} \mathrm{OCl}\right)\right]$ shows a molecular ion peak at $\mathrm{m} / \mathrm{z}$ 339.09 (I) due to $[\mathrm{Zn}(\mathrm{L})]^{+\bullet}$ which suggests the monomeric nature of the complex. The intense peak at $\mathrm{m} / \mathrm{z} 238.1$ (IV) corresponds to loss of ligand molecule $\mathrm{L}^{+\bullet}$, that is, $\left(\mathrm{C}_{14} \mathrm{H}_{10} \mathrm{~N}_{3} \mathrm{O}\right)^{+\bullet}$ from (II), indicating molecular mass of the ligand. Other peaks of appreciable intensity observed at $\mathrm{m} / \mathrm{z}$ values of 306.54 (II) due to loss of $(\mathrm{Cl})^{+\bullet}$ from (I), at $\mathrm{m} / z 249.64$ (III) due to loss of $\left(\mathrm{C}_{4} \mathrm{H}_{4}\right)^{+\bullet}$ from (II), and at $\mathrm{m} / z 183.1(\mathrm{~V})$ due to loss of $\left(\mathrm{C}_{4} \mathrm{H}_{4}\right)^{+\bullet}$ from (IV), and base peak at $m / z 134.1$ (VI) is due to loss of $\left(\mathrm{C}_{7} \mathrm{H}_{5} \mathrm{~N}_{3}\right)^{+\bullet}$ from (IV). An intense peak formed at (VI) indicates loss of the 2-aminobenzimidazole ring. The relative intensities of these peaks give an assessment of the stabilities of the various fragments. Such type of fragmentation patterns has been reported by many workers [33-35].

3.4. Antimicrobial Study. The pure compound does not show any biological activity but the synthesized Schiff base and the complex showed moderate to good biological activity against all microbes. In case of bacterial strains E. coli showed good activity in both Schiff base and the complex whereas others showed moderate to zero activity [36].

But in case of fungal strains $A$. niger has zone of inhibition ranging between $1.15 \mathrm{~mm}$ and $3.41 \mathrm{~mm}$ with the metal complex having maximum zone of inhibition more than the derived Schiff base. Further, in case of C. albicans, the effective antifungal activity was shown again by the complex with $3.20 \mathrm{~mm}$ zone of inhibition (Table 4 ), whereas the Schiff base showed moderate activity having $1.35 \mathrm{~mm}$ zone of inhibition compared to the complex [37]. 
TABLE 3: Antibacterial activity of pure compound, its ligand, and metal complex.

\begin{tabular}{lcccc}
\hline Compounds/complexes $(100 \mu \mathrm{g} / \mathrm{mL})$ & B. subtilis & S. aureus & E. coli & K. pneumoniae \\
\hline $\mathrm{Ab}$ & - & - & - & 1.15 \\
$\mathrm{Ab}-\mathrm{S}$ & 0.9 & - & 1.15 & 1.15 \\
{$[\mathrm{Zn}(\mathrm{Ab}-\mathrm{S}) \mathrm{Cl}]$} & 1.3 & - & 2.0 & - \\
$\mathrm{Chloramphenicol} 10 \mu \mathrm{g}(4 \mathrm{~mm})$ & 2.0 & 2.15 & 2.5 \\
\hline
\end{tabular}

TABLE 4: Antifungal activity of pure compound, its ligand, and metal complex.

\begin{tabular}{lcc}
\hline Compounds/complexes $(100 \mu \mathrm{g} / \mathrm{mL})$ & \multicolumn{2}{c}{ Diameter of growth of inhibition zone (mm) } \\
Candida albicans & Aspergillus niger \\
\hline $\mathrm{Ab}$ & - & - \\
$\mathrm{Ab}-\mathrm{S}$ & 1.35 & 3.15 \\
{$[\mathrm{Zn}(\mathrm{Ab}-\mathrm{S}) \mathrm{Cl}]$} & 3.20 & 3.41 \\
$\mathrm{Griseofulvin}(10 \mu \mathrm{g} / \mathrm{mL}) 5.5 \mathrm{~mm}$ & 3.45 & 3.95 \\
\hline
\end{tabular}

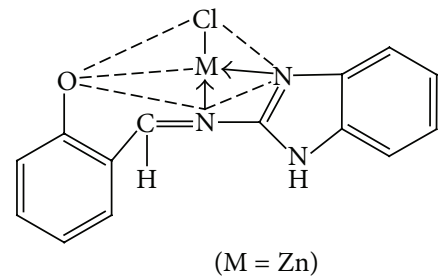

Figure 3: Structure of the metal complex.

Thus, it can be said that complexation or chelation increases the antimicrobial activity.

\section{Conclusion}

The study of the reaction between the transition metal and the derived Schiff base indicates its high stability. This encourages the synthesis and careful investigation of the nature of bonding between the Schiff base and the transition metal cation of important biological role, using physicochemical method of analyses. It is clear from above discussion that the fragmentation pattern and spectral studies of the complex confirm and illustrate the proposed geometry obtained by elemental analysis, IR, ${ }^{1} \mathrm{H}$ NMR, and mass spectra.

Hence, the proposed tentative structure of the metal complex is given as in Figure 3.

\section{Conflict of Interests}

The authors declare that there is no conflict of interests regarding the publication of this paper.

\section{References}

[1] Y. Shibuya, K. Nabari, M. Kondo et al., "The copper(II) complex with two didentate schiff base ligands. The unique rearrangment that proceeds under alcohol vapor in the solid state to construct noninclusion structure," Chemistry Letters, vol. 37, no. 1, pp. 7879, 2008.
[2] B. J. Gangani and P. H. Parsania, "Microwave-irradiated and classical syntheses of symmetric double Schiff bases of $1,1^{\prime}$-bis(4-aminophenyl)cyclohexane and their physicochemical characterization," Spectroscopy Letters, vol. 40, no. 1, pp. 97-112, 2007.

[3] B. S. Kumari, G. Rijulal, and K. Mohanan, "Microwave assisted synthesis, spectroscopic, thermal and biological studies of some lanthanide(III) chloride complexes with a heterocyclic schiff base," Synthesis and Reactivity in Inorganic, Metal-Organic and Nano-Metal Chemistry, vol. 39, no. 1, pp. 24-30, 2009.

[4] M. Thankamony and K. Mohanan, "Synthesis, spectral studies, thermal decomposition kinetics, reactivity and antibacterial activity of some lanthanide(III) nitrate complexes of 2(N-indole-2-one)amino-3-carboxyethyl-4,5,6,7-tetrahydrobenzo[b]thiophene," Indian Journal of Chemistry A, vol. 46, no. 2, pp. 247-251, 2007.

[5] N. Raman, J. D. Raja, and A. Sakthivel, "Synthesis, spectral characterization of Schiff base transition metal complexes: DNA cleavage and antimicrobial activity studies," Journal of Chemical Sciences, vol. 119, no. 4, pp. 303-310, 2007.

[6] B. Halli and V. B. Patil, "Synthesis, spectral characterization and DNA cleavage studies of $\mathrm{Co}(\mathrm{II}), \mathrm{Ni}(\mathrm{II}), \mathrm{Cu}(\mathrm{II}), \mathrm{Zn}(\mathrm{II}), \mathrm{Cd}(\mathrm{II})$ and $\mathrm{Hg}$ (II) complexes with benzofuran-2-carbohydrazide schiff bases," Indian Journal of Chemistry A, vol. 50, no. 5, pp. 664-669, 2011.

[7] K. Shivakumar and M. B. Halli, "Synthesis, characterization and antimicrobial studies on metal complexes with a naphthofuran thiosemicarbazide derivatives," Journal of Coordination Chemistry, vol. 59, no. 16, pp. 1847-1856, 2006.

[8] N. Bharti, S. Sharma, F. Naqvi, and A. Azam, "New palladium(II) complexes of 5-nitrothiophene-2-carboxaldehyde thiosemicarbazones: synthesis, spectral studies and in vitro anti-amoebic activity," Bioorganic \& Medicinal Chemistry, vol. 11, no. 13, pp. 2923-2929, 2003.

[9] A. A. Soliman, "Synthesis and properties of new substituted 1,2,4-triazoles: potential antitumor agents," Journal of Thermal Analytic Calculation, no. 63, p. 221, 2001.

[10] A. F. Petrovic, D. M. Petrovic, V. M. Leovac, and M. Budimir, "Ruthenium(II) complexes containing bidentate Schiff bases and their antifungal activity," Journal of Thermal Analytic Calculation, vol. 58, p. 589, 1999.

[11] Ivanovic, K. Andjelkovic, V. M. Leovac, L. J. Klisarov, M. Lazavevic, and D. Minic, "Molecular design of mononuclear 
complexes of acyclic Schiff-base ligands, Journal of Coordination Chemistry," Journal of Thermal Analytic Calculation, vol. 46, p. 1741, 1996.

[12] Z. M. Zaki, S. S. Haggag, and A. A. Soayed, "Synthesis, spectral characterization and DNA cleavage studies of $\mathrm{Co}(\mathrm{II}), \mathrm{Ni}(\mathrm{II})$, $\mathrm{Cu}(\mathrm{II}), \mathrm{Zn}(\mathrm{II}), \mathrm{Cd}(\mathrm{II})$ and $\mathrm{Hg}(\mathrm{II})$ complexes with benzofuran2- carbohydrazide schiff bases," Spectroscopy Letters, vol. 31, p. $757,1998$.

[13] S. O. Podunavac-Kuzmanovic, D. M. Cvetkovicand, and L. S. Vojinnovic, "Synthesis, characterization and molecular structure of a new tetramericpalladium ( II) complex containing Schiff bases derived from AMTTO (AMTT = 4-amino-6methyl-1,2,4-triazine-thione-5-one)," Original Scientific Paper, APTEFF, vol. 35, pp. 1-280, 2004.

[14] A. Mobinikhaledi, N. Forughifar, and M. Kalhor, "Synthesis, characterization, DNA binding and nuclease activity of binuclear copper( II) complexes of cuminaldehydethiosemicarbazones," Turkish Journal of Chemistry, vol. 34, pp. 367-373, 2010.

[15] S. O. Podunavc-Kuzmanovic, L. Vojinovic, and D. M. Cvetkovic, "Synthesis, structure and biological activity of a new and efficient Cd(II)-uracil derivative complex system for cleavage of DNA," ISIRR, vol. 64, pp. 40-44, 2003.

[16] I. Vogel, Quantitative Inorganic Analysis, Longman Green and Co, London, UK, 1959.

[17] C. Perez, M. Paul, and p. Bazerque, "An antibiotic assay by the agar well diffusion method," Acta Biologiae et Medicinae Experimentalis, vol. 15, pp. 113-115, 1990.

[18] R. Nair, T. Kalyariya, and S. Chanda, "Antibacterial activity of some selected Indian medicinal flora," Turkish Journal of Biology, vol. 29, pp. 41-47, 2005.

[19] K. Singh, Y. Kumar, P. Puri, C. Sharma, and K. R. Aneja, "Synthesis, spectroscopic, thermal and antimicrobial studies of $\mathrm{Co}(\mathrm{II}), \mathrm{Ni}(\mathrm{II}), \mathrm{Cu}(\mathrm{II})$ and $\mathrm{Zn}(\mathrm{II})$ complexes with Schiff base derived from 4-amino-3-mercapto-6-methyl-5-oxo-1,2,4triazine," Medicinal Chemistry Research, vol. 21, no. 8, pp. 17081716, 2012.

[20] W. J. Geary, "The use of conductivity measurements in organic solvents for the characterisation of coordination compounds," Coordination Chemistry Reviews, vol. 7, no. 1, pp. 81-122, 1971.

[21] P. Murali Krishna, K. Hussain Reddy, J. P. Pandey, and S. Dayananda, "Synthesis, characterization, DNA binding and nuclease activity of binuclear copper(II) complexes of cuminaldehyde thiosemicarbazones," Transition Metal Chemistry, vol. 33, no. 5, pp. 661-668, 2008.

[22] K. Shanker, R. Rohini, K. Shravankumar, P. M. Reddy, Y.-P. Ho, and V. Ravinder, "Synthesis of tetraaza macrocyclic PdII complexes; antibacterial and catalytic studies," Journal of the Indian Chemical Society, vol. 86, no. 2, pp. 153-161, 2009.

[23] M. L. Hari Kumaran Nair and L. Shamla, "Synthesis, spectral and thermal studies of copper(II) complexes of azodyes derived from 2,3-dimethyl-1-phenyl-4-amino-5-pyrazolone," Journal of the Indian Chemical Society, vol. 86, no. 2, pp. 133-138, 2009.

[24] V. Reddy, N. Patil, and B. R. Patel, "Synthesis and characterization of $\mathrm{Co}(\mathrm{II}), \mathrm{Ni}(\mathrm{II})$, and (II) complexes with $\mathrm{O}, \mathrm{N}$ and $\mathrm{S}$ donar ligands," Journal of Indian Council of Chemists, vol. 23, no. 2, pp. $1-3,2006$.

[25] V. D. Bhatt and A. Ray, "Synthesis, characterization and electrical conductivity of polyesters, polyamides and doped polymers," Synthetic Metals, vol. 92, no. 2, pp. 115-120, 1998.

[26] D. Prakash, C. Kumar, S. Prakash, A. K. Gupta, and K. R. R. P. Singh, "Synthesis, spectral characterization and antimicrobial studies of some new binuclear complexes of CuII and NiII Schiff base," Journal of the Indian Chemical Society, vol. 86, no. 12, pp. 1257-1261, 2009.

[27] N. Raman, S. Esthar, and C. Thangaraja, "A new Mannich base and its transition metal (II) complexes-synthesis, structural characterization and electrochemical study," Journal of Chemical Sciences, vol. 116, no. 4, pp. 209-213, 2004.

[28] M. Revanasiddapa, T. Suresh, S. Khasim, S. C. Raghvendra, C. Basvaraja, and S. D. Angadi, "Synthesis and anti-tuberculosis activity of N-aryl-C-nitroazoles," Egyptian Journal of Chemistry, vol. 5, no. 2, p. 395, 2008.

[29] A. H. Osman, M. S. Saleh, and S. M. Mahmoud, "Synthesis, characterization, and photochemical studies of some copper complexes of schiff bases derived from 3-hydrazino6-methyl $[1,2,4]$ triazin-5(4H) one," Synthesis and Reactivity in Inorganic and Metal-Organic Chemistry, vol. 34, no. 6, pp. 10691085, 2004.

[30] A. D. Kulkarni, S. A. Patil, and P. S. Badami, "SNO donor Schiff bases and their $\mathrm{Co}(\mathrm{II}), \mathrm{Ni}(\mathrm{II})$ and $\mathrm{Cu}(\mathrm{II})$ complexes: synthesis, characterization, electrochemical and antimicrobial studies," Journal of Sulfur Chemistry, vol. 30, no. 2, pp. 145-159, 2009.

[31] K. Singh, Dharmapal, and S. S. Dheman, "Synthesis and characterization of $\mathrm{Co}(\mathrm{II}), \mathrm{Ni}(\mathrm{II})$, and $\mathrm{Cu}(\mathrm{II})$ complexes with $\mathrm{O}, \mathrm{N}$ and S donor ligands," Journal of the Iranian Chemical Society, vol. 7, no. $1,2010$.

[32] A. S. Kuwar, S. R. Shimpi, P. P. Madhukar, and R. S. Bhendre, "Synthesis of tetraazamacrocyclic PdII complexes; antibacterial and catalytic studies Journal of the Indian Chemical Society," Journal of Scientific and Industrial Research, vol. 65, p. 665, 2006.

[33] S. Chandra and A. Kumar, "Synthesis, characterization and antimicrobial studies on metal complexes with a naphthofuranthiosemicarbazide derivatives," Journal of the Indian Chemical Society, vol. 83, p. 993, 2006.

[34] A. Kashem Liton and M. Rabiul Islam, “The copper( II) complex with two didentateschiff base ligands. The unique rearrangment that proceeds under alcohol vapor in the solid state to construct noninclusion structure," Journal of Pharmacology, no. 1, p. 10, 2006.

[35] R. Franski, B. Giercyzyk, G. Schroeder, S. Pieper, A. Springer, and M. Linscheid, "Antibacterial $\mathrm{Co}(\mathrm{II}), \mathrm{Ni}(\mathrm{II}), \mathrm{Cu}(\mathrm{II})$ and $\mathrm{Zn}$ (II) complexes of Schiff bases derived from fluorobenzaldehyde and triazoles," Central European Journal of Chemistry, vol. 5, no. 1, pp. 316-329, 2007.

[36] G. B. Bagihalli, P. G. Avaji, S. A. Patil, and P. S. Badami, "Synthesis, spectral characterization, in vitro antibacterial, antifungal and cytotoxic activities of $\mathrm{Co}(\mathrm{II}), \mathrm{Ni}(\mathrm{II})$ and $\mathrm{Cu}(\mathrm{II})$ complexes with 1,2,4-triazole Schiff bases," European Journal of Medicinal Chemistry, vol. 43, no. 12, pp. 2639-2649, 2008.

[37] A. K. Singh, O. P. Pandey, and S. K. Sengupta, "Synthesis, spectral characterization and biological activity of zinc(II) complexes with 3-substituted phenyl-4-amino-5-hydrazino-1, 2, 4triazole Schiff bases," Spectrochimica Acta-Part A: Molecular and Biomolecular Spectroscopy, vol. 85, no. 1, pp. 1-6, 2012. 

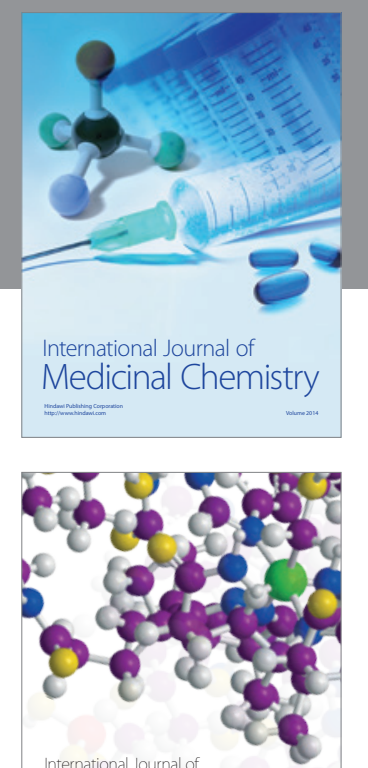

\section{Carbohydrate} Chemistry

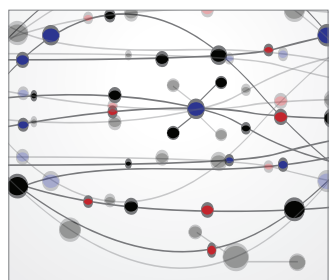

The Scientific World Journal
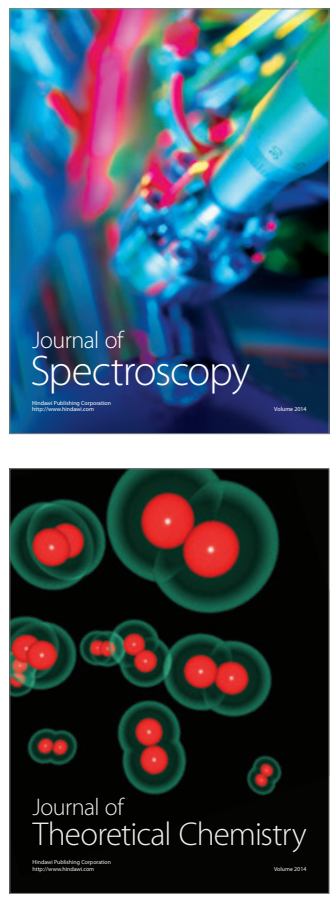
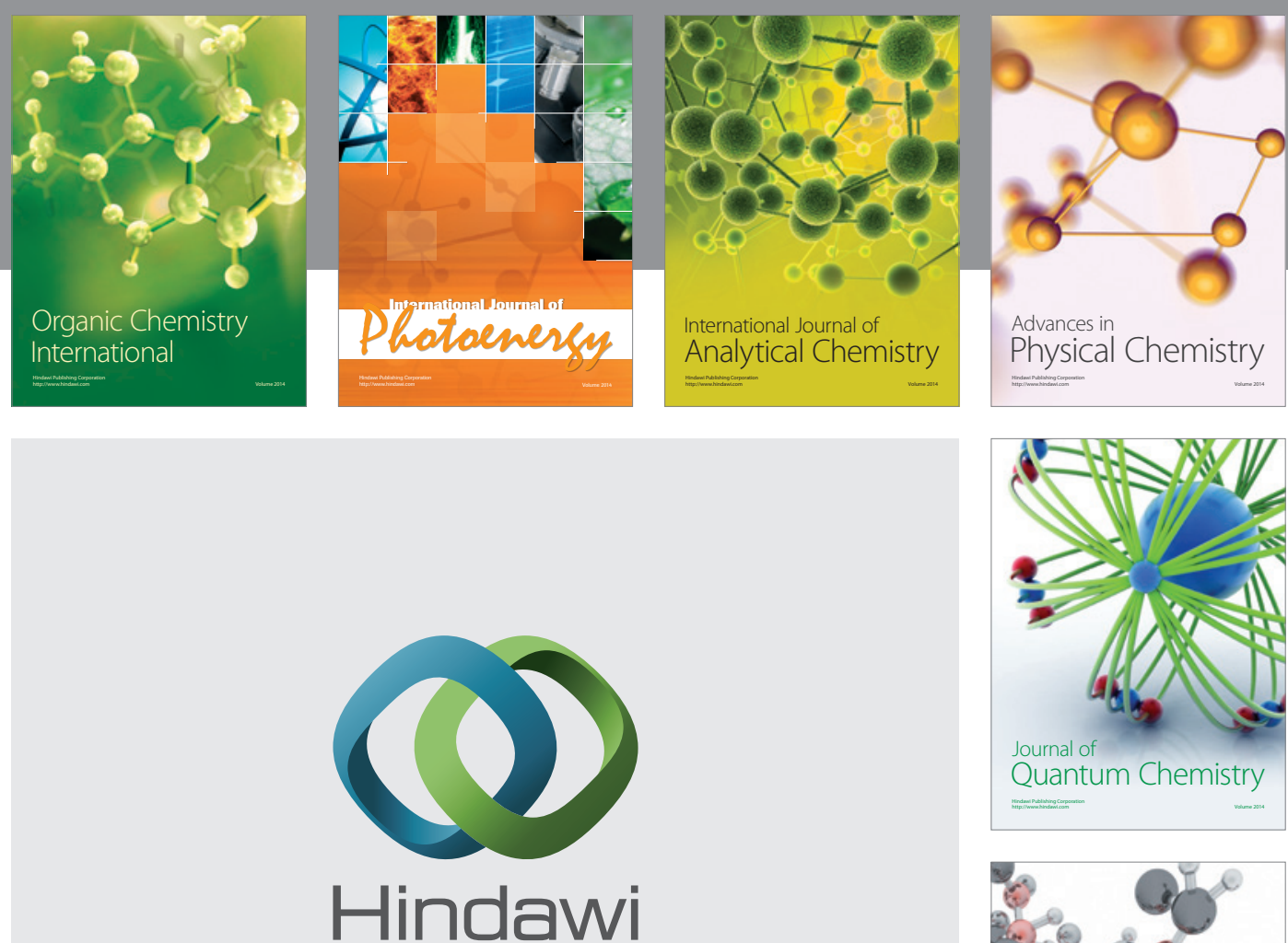

Submit your manuscripts at

http://www.hindawi.com

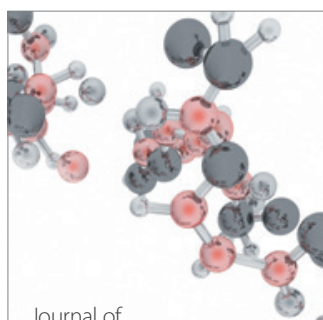

Analytical Methods

in Chemistry

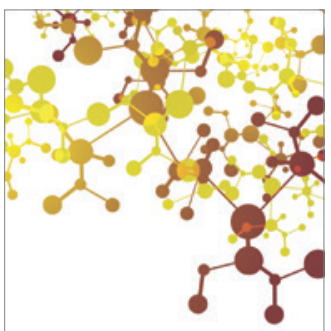

Journal of

Applied Chemistry

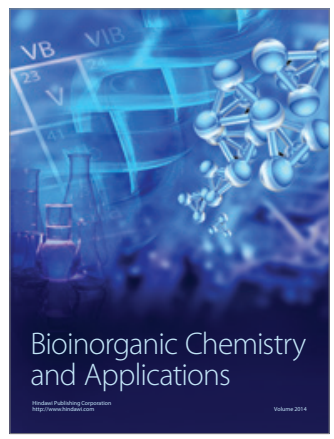

Inorganic Chemistry
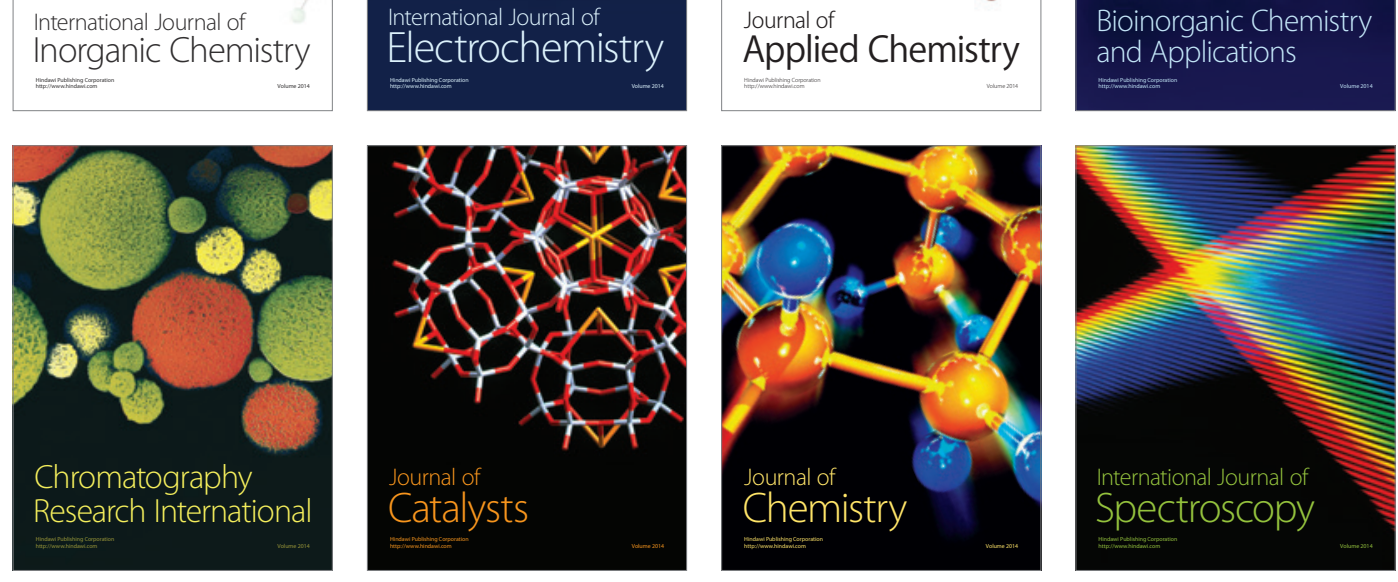